\title{
Application of Process Hierarchy Analysis as A Direction of Economic Development in West Coast District
}

\author{
By: \\ Feri Hardani ${ }^{*}$, Toto Gunarto, Neli Aida \\ Faculty of Economics and Business, University of Lampung \\ ${ }^{*}$ Coresponding Author: ferhardani@gmail.com \\ Submission: August 6, 2021; Accepted: September 30, 2021
}

\begin{abstract}
West Coast District as a district that has just been established must be able to catch up with progress in other areas, of course as a new district, the hope is that this area will expand so that the region can develop more independently and bring prosperity to the residents of the West Coast District, economic development can be done by through community aspirations or what is commonly referred to as community participation in development, so that in the development process the community is involved and the development implemented will be right on the recommendation. This study aims to determine how the perceptions of the people of the West Coast District regarding regional economic development, and which sectors want to become development priorities, with the great potential that the region has, namely tourism which is well known even to foreign countries, making people want the local government to make the tourism sector as a tourism sector. sectors that are prioritized for development. This study uses process hierarchy analysis (AHP), as a method to see people's perceptions of development.
\end{abstract}

Keywords:Strategy; Region, Priority, Economic

\begin{abstract}
ABSTRAK
Kabupaten West Coast sebagai kabupaten yang baru saja berdiri tentu harus mampu untuk mengejar kemajuan yang ada didaerah lain, tentu sebagai kabupaten baru, harapan dimekarkannya daerah ini agar daerah dapat membangun dengan lebih mandiri dan membawa kesejahteraan bagi warga Kabupaten Pesisir Barat, namun sampai saat ini kabupaten Pesisir Barat merupakan salah satu kabupaten tertinggal di provinsi lampung. Penelitian ini bertujuan untuk mengetahui bagaimana persepsi masyarakat kabupaten Pesisir Barat terkait pembangunan perekonomian daerahnya, dan sektor mana yang yang ingin menjadi prioritas pembangunan. Penelitian ini menggunakan analisis hierarki proses $(A H P)$, sebagai metode untuk melihat persepsi masyarakat terhadap pembangunan. Berdasarkan hasil penelitian menunjukkan bahwa masayarakat mengharapkan pembangunan sektor pariwisata sebagai sektor utama diikuti dengan sektor perikanan, industri dan kehutanan, berdasarkan hasil penelitian ini, diharapkan pemerintah daerah dapat melihat keinginan masyarakat terhadap pembangunan, sehingga sinergitas antara pemerintah daerah dan masyarakat akan mempercepat proses pembangunan dan peningkatan taraf hidup masyarakat.
\end{abstract}

Kata Kunci: Strategi, Wilayah, Prioritas Pembangunan Ekonomi, 


\section{INTRODUCTION}

According to the Ministry of Villages, Development of Disadvantaged Regions, and Transmigration, there are 2 types of regions, namely disadvantaged areas and areas that are not left behind or developing, underdeveloped areas are districts that are relatively underdeveloped compared to other regions on a national scale, and have relatively underdeveloped populations

Presidential Regulation Number 63 of 2020 concerning the Determination of Disadvantaged Regions for 2020-2024 states, underdeveloped areas are districts whose territories and communities are less developed than other regions on a national scale. According to the presidential regulation, the determination of underdeveloped regions by the government is carried out every five years nationally based on criteria, indicators, and sub-indicators of lagging regions. President Joko Widodo (Jokowi) has determined that West Coast District is the only underdeveloped area in Lampung Province. President Jokowi has signed Presidential Regulation (Perpres) No. 63 of 2020 concerning the determination of the Disadvantaged Regions for 2020-2024.

From Presidential Regulation (Perpres) No. 63 of 2020, apart from the West Coast District, there are 62 regions that are also designated as underdeveloped areas in Indonesia. The West Coast District has a lot of potential to advance its regional economy, such as tourism, agriculture, fisheries, and forestry. The following shows the economic structure of the West Coast District through GRDP data.

Table 1. Gross Regional Domestic Product (GDP) at Constant Prices (ADHK) 2010 Series by West Coast Business Field 2016-2020 (Billion Rupiah)

\begin{tabular}{llrrrrr}
\hline \multirow{2}{*}{ No } & & \multicolumn{5}{c}{ Year } \\
\cline { 2 - 6 } & & 2016 & 2017 & 2018 & 2019 & 2020 \\
\hline A & Agriculture, Forestry and Fisheries & 1399.12 & 1443.17 & 1486.37 & 1507.06 & 1507.16 \\
$\mathrm{~B}$ & Mining and excavation & 136.17 & 149.74 & 161.22 & 170.48 & 166.24 \\
$\mathrm{C}$ & Processing industry & 141.81 & 144.94 & 147.17 & 145.23 & 126.99 \\
$\mathrm{D}$ & Procurement of Electricity, Gas & 0.29 & 0.37 & 0.44 & 0.55 & 0.58 \\
$\mathrm{E}$ & Water Supply & 1.33 & 1.33 & 1.41 & 1.44 & 1.51 \\
$\mathrm{~F}$ & Construction & 135.58 & 155.14 & 176.62 & 226.95 & 222.35 \\
$\mathrm{G}$ & Wholesale Trade and Vehicle Repair & 313.63 & 335.63 & 362.01 & 396.09 & 380.44 \\
$\mathrm{H}$ & Transportation and Warehousing & 26.73 & 28.54 & 30.38 & 32.66 & 31,12 \\
I & Information and Communication & 38.51 & 42.37 & 46.53 & 51.33 & 48.97 \\
$\mathrm{~J}$ & Provision of Accommodation and & 56.7 & 63.39 & 68.87 & 72.82 & 79.14 \\
& Food and Drink & & & & & \\
K & Financial Services & 39.4 & 40.94 & 41.86 & 43.11 & 43.23 \\
$\mathrm{~L}$ & Real Estate & 101.08 & 108.39 & 115.06 & 122.25 & 117.61 \\
$\mathrm{M} \mathrm{N}$ & Company Services & 3.56 & 3.81 & 3.96 & 4.29 & 4.22 \\
$\mathrm{O}$ & Government Administration and & 117.59 & 125.7 & 136.8 & 148.47 & 150.46 \\
& Others & & & & & \\
$\mathrm{P}$ & Education Services & 89.54 & 94.2 & 102.62 & 111.35 & 115.9 \\
$\mathrm{Q}$ & Health Services and Social Activities & 28.24 & 29.88 & 32.33 & 35.11 & 38.45 \\
$\mathrm{R}, \mathrm{S}, \mathrm{T}, \mathrm{U}$ & Other services & 25.27 & 28.42 & 31.25 & 33.81 & 32.29 \\
\hline Gross Regional Domestic Product & 2654.54 & 2795.95 & 2944.88 & 3103 & 3066,66 \\
\hline
\end{tabular}

Source: BPS West Coast District

Based on the data in the table above, it can be seen that the economic structure of the west coast district is dominated by the agricultural sector, based on presidential regulation number 63 of 2020 concerning the determination of underdeveloped areas 2020-2025 west coast districts are included in the list of disadvantaged areas in Indonesia, underdeveloped areas are districts whose regions and communities are less developed than other regions on a national scale. As an underdeveloped area, of course there are several things that must be improved and improved. 
Underdeveloped areas are determined based on criteria, including the community economy, based on this, economic development and development is needed, the role of the community is needed in economic development,

Economic growth can have a positive impact on poverty reduction if the economic growth that occurs is in favor of the poor. Economic growth is a necessary condition for poverty reduction, while the sufficient condition is that economic growth must be effective in reducing poverty. This means that growth should spread across every income group, including the poor (growth with equity). Directly, this means that growth needs to be ensured in sectors where the poor work (agriculture or laborintensive sectors). As for indirectly, it means that a government that is quite effective in redistributing the benefits of growth is needed. (Siregar 2006),

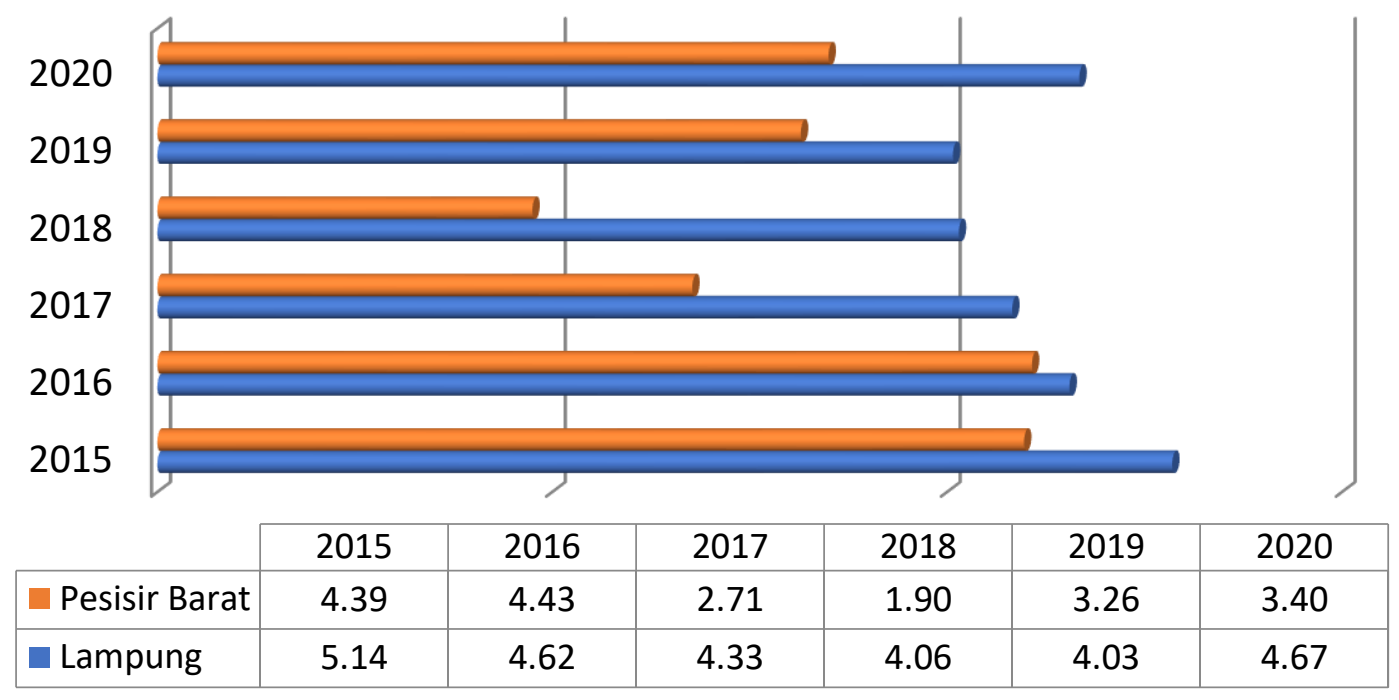

Source: BPS Lampung Province

Figure 1. The Open Unemployment Rate in West Coast District 2015-2020

community participation for successful development emerged because of a shift in development orientation from the capital investment growth model developed in the 60 s to the people centered basic needs approach orientation in the 70s. The change in development orientation stems from the fact that the poor in economic development are not raised much in the progress of development. In practice, community participation in development activities occurs not because of the voluntary basis of the community itself, but because it is forced through mobilization. (Zamor, 1985), based on this theory, this research would be appropriate to involve the community in the development process.

Regional economic development is a process in which local governments and communities manage existing resources and form a partnership pattern between local governments and the private sector to create new jobs and stimulate the development of economic activity (economic growth) in the region. (Arsyad, 1999). The success of development in the region is very dependent on the potential it has, as well as the management of that potential. For this reason, regions are required to always improve their capabilities in managing their regional potential. Based on Law no. 23 of 2014 concerning Regional Government, regional governments have broader authority to regulate and manage various government administration affairs for the interests and welfare of the local community concerned.

To realize the goals of regional development, it is necessary to have cooperation and synergy between the government, the community, the private business world. Governments with limited budgets need support from the public and private entrepreneurs. This condition applies at all levels of government, both central and regional, including the West Coast District Government.

Variations in the implementation of development conceptually recognize several approaches, including (a) a top-down social development approach, (b) a community-based resource management 
approach to social development, (c) a regional approach with integrated multi-sectoral targets, (d) social development approach by involving NGOs, (e) resource mobilization approach through stimulation from the center, see Tjokrowinoto, Politics of Development, Op.Cit. pages 42-53.

In the modern era like today, community participation in regional development, especially in the economic sector can be done, either voluntarily or by making a system. are expected to be able to answer which sectors are desired to be developed and are expected to be able to support people's lives and have an impact on welfare.

Agricultural Subsector Development Strategy in Bogor District by Using the Analytical Hierarchy Process (AHP) Method (Ramadhan, 2017). This determination aims to determine the leading sectors in Bogor District, determine changes in the economic sector in Bogor District, and determine sector priorities to be developed in Bogor District.

Industrial Development Planning Strategy Based on Regional Leading Products, Study at the Industry and Trade Office of Blitar District (Pradigda, 2016). This study aims to determine the superior product that is prioritized or called the priority superior product in Blitar District, which is the location for its development. The analytical methods used in this research are shift-share analysis and Analytical Hierarchy Process (AHP),

Analysis of development strategies for underdeveloped areas as an effort to accelerate economic development In the west coast district (Agustin, 2020), this study uses a SWOT analysis tool, based on this research the main strength of West Coast District is an area with great potential as tourism, the main weakness of West Coast District indicated by the strategic factors of community poverty, the main opportunity for West Coast District is the rapid development of technology, which is the main threat to West Coast District is prone to natural disasters.

Based on previous research, this research was conducted to see how the perception of the people of the West Coast District is related to the economic sector that will be developed in the West Coast District. Research conducted by Erlin Agustin in 2020, the development strategy of the West Coast District area is carried out by improving the quality of infrastructure, and marketing potential, so this research will further refine the economic development strategy in the West Coast District. regarding the development of the economic sector, what is desired for the development process to be prioritized.

\section{METHODS}

This research is a descriptive analysis research. To answer the purpose of this research, the writer will use process hierarchy analysis, the Analytical Hierarchy Process (AHP) was first developed by Thomas Lorie Saaty from Wharton Business School in the 1970s, which is used to find ranking or order of priority of various alternatives in solving a problem. The advantage of this AHP is its ability when faced with complex or framed situations where there is little statistical information about the problem at hand. Existing data are only qualitative in nature based on perception, experience, or intuition. So, the problem can be felt and observed, but the completeness of the numerical data does not support it to be modeled quantitatively. (Suyono \& Mukti, 2009).

In the Process Hierarchy Analysis (AHP) method using a scale for assessment, the scale used is $1=$ Goals are equally important with each other, $3=$ Goals are slightly more important (somewhat strong) than other goals, $5=$ Goals are one are more important (stronger importance) than other goals, $7=$ One goal is very important than the other goals, $9=$ One goal is extreme in importance than the other goals, 2,4,6,8 = Middle value between two values rating score above. 


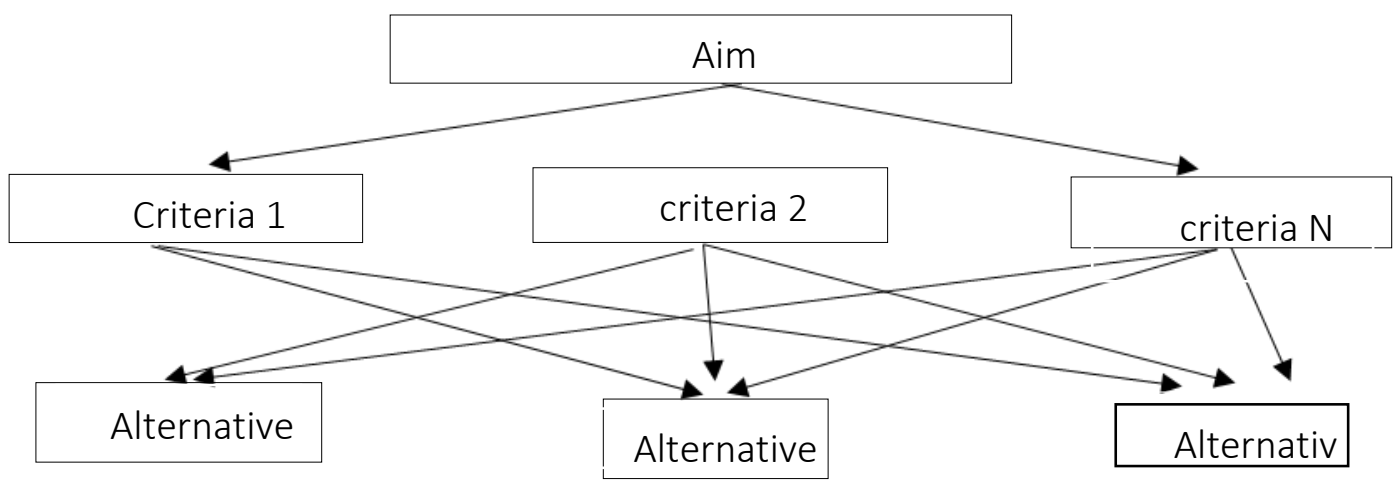

Figure 2. Structure of Process Hierarchy Analysis.

In the Process Hierarchy Analysis there is a pairwise comparison against a specified criterion. The comparison is transformed in the form of a matrix known as a comparison matrix (pairwise comparison). For example, there are $n$ objects denoted by $(A 1, A 2, \ldots, A n)$ which will be assessed based on their importance. This matrix is illustrated in the following table.

Table 2. Pairwise comparison matrix

\begin{tabular}{cccc}
\hline C & A1 & A2 & An \\
\hline A1 & $a 11$ & $a 12$ & $a 1 n$ \\
A2 & $a 21$ & $a 22$ & $a 2 n$ \\
An & $\vdots$ & $\vdots$ & $\vdots$ \\
\hline
\end{tabular}

The sample is part of a population that will represent the object of research. The method or technique used in this research is purposive sampling. Purposive sampling is a technique for determining research samples with certain considerations aimed at making the resulting data more representative. (Sugiyono, 2012:126), The following are the criteria for determining purposive sampling.

Table 3. Respondent Criteria

\begin{tabular}{cll}
\hline No & \multicolumn{1}{c}{ Respondent } & \\
\hline 1 & Local Government & a. Holding positions related to industrial products \\
& (Department & b. Experience in position minimum five years \\
& related to industry) & c. Control field planning and industrial development \\
2 & Private (KADIN) & a. Manager at regional business association \\
& & b. In charge of MSME \\
3 & Public & c. Minimum five years work experience \\
& & a. Has been in the MSME sector \\
& b. Have been in the industrial or environmental field
\end{tabular}

As well as the public represented by the community engaged in the MSME sector as many as 3 people. Total respondents are 42 respondents

AHP is a decision support model developed by Thomas L. Saaty. The characteristic of this analysis is to use a hierarchy that describes the problem in a single unit into simpler elements. The hierarchy in this analysis is divided into goals, scenarios, goals, and strategies. AHP is a mathematical decision-making technique by considering both qualitative and quantitative aspects.

AHP is a concept for multicriteria-based decision making. Several criteria are compared with each other (level of importance) is the main emphasis on this AHP concept (Nugeraha 2017:114). In AHP, what is measured is the consistency ratio by looking at the consistency index. The expected 
consistency is near perfect to produce a decision that is close to valid. Thus, this study did not test the validity or reliability of the AHP questionnaire because AHP tolerates inconsistency. AHP is measured by the Consistency Index $(\mathrm{Cl})$ and Consistency Ratio (CR) with the following description:

Count Consistency Index $(\mathrm{Cl})$ with the formula:

Where:

$$
\mathrm{Cl}=(\pi \max -n) /(n-1)
$$

$\mathrm{n} \quad$ : number of elements

Calculating the Consistency Ratio (CR) with the formula:

Where:

$$
\mathrm{CR}=\mathrm{Cl} / \mathrm{IR}
$$

\section{CR : Consistency ratio \\ $\mathrm{Cl} \quad$ : Consistency Index \\ IR : Index Random Consistency}

In general, a certain level of consistency is needed in determining priorities to obtain valid results. For this reason, in AHP, the CR value should not be more than $10 \%$ or 0.1 . Then in processing the results of the AHP questionnaire, it will be carried out using the Expert Choice 11 application. The basic principles in the AHP calculation are:

Decomposition At this stage, the problem to be studied is divided into a hierarchy. The goal is to define the problem from the general to the specific. The hierarchical structure serves to compare the objectives, criteria, and alternative levels. The top level of the hierarchy is the goal of solving a problem that has only one element. The next stage has several elements as criteria, each of which can be compared with one another, and the differences are not too big. If the difference is too large, then a new level must be created. The form of the decomposition structure is:

$\begin{array}{ll}\text { First tier } & \text { : Decision goal (Goal) } \\ \text { Second level } & \text { : Criteria } \\ \text { Third tier } & \text { : Alternative }\end{array}$

The consistency ratio by looking at the consistency index is the thing that is measured in the hierarchical analysis of the process, the expected consistency is near perfect to produce a decision that is close to valid. AHP is measured by Consistency Index (CI) and Consistency Ratio (CR). The preparation of the process hierarchy analysis diagram is shown in the following figure.

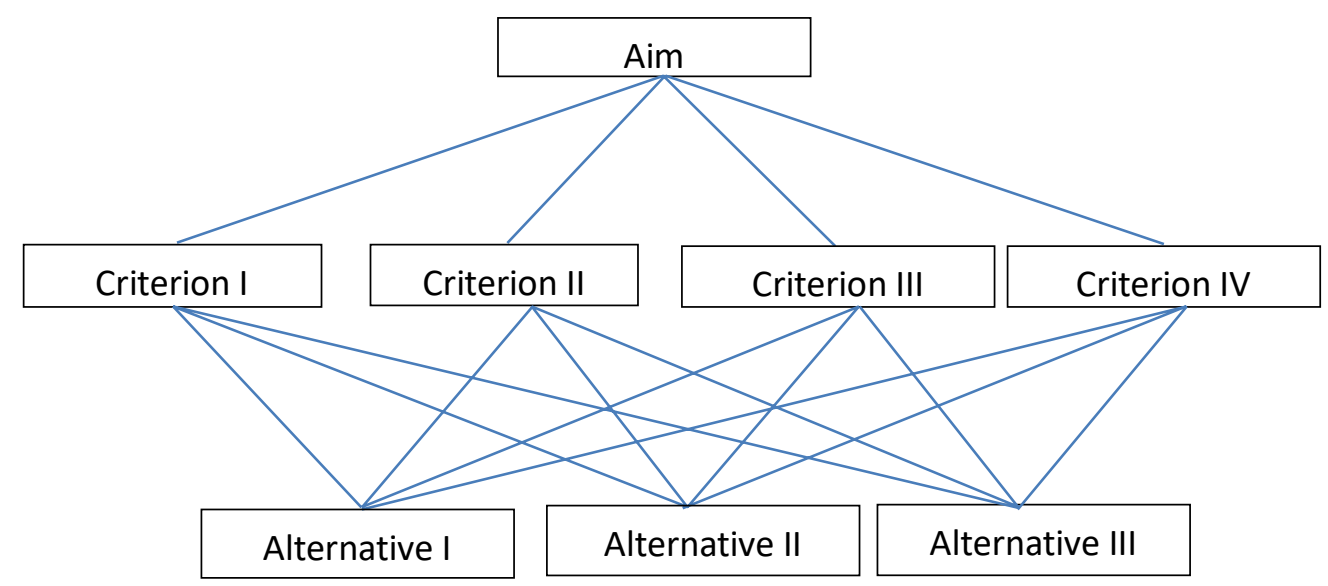

Figure 3 Process Hierarchy Analysis Matrix

Based on the figure above, a process hierarchy analysis matrix can be compiled in this study, the following is a process hierarchy analysis matrix that has been compiled in this study. 


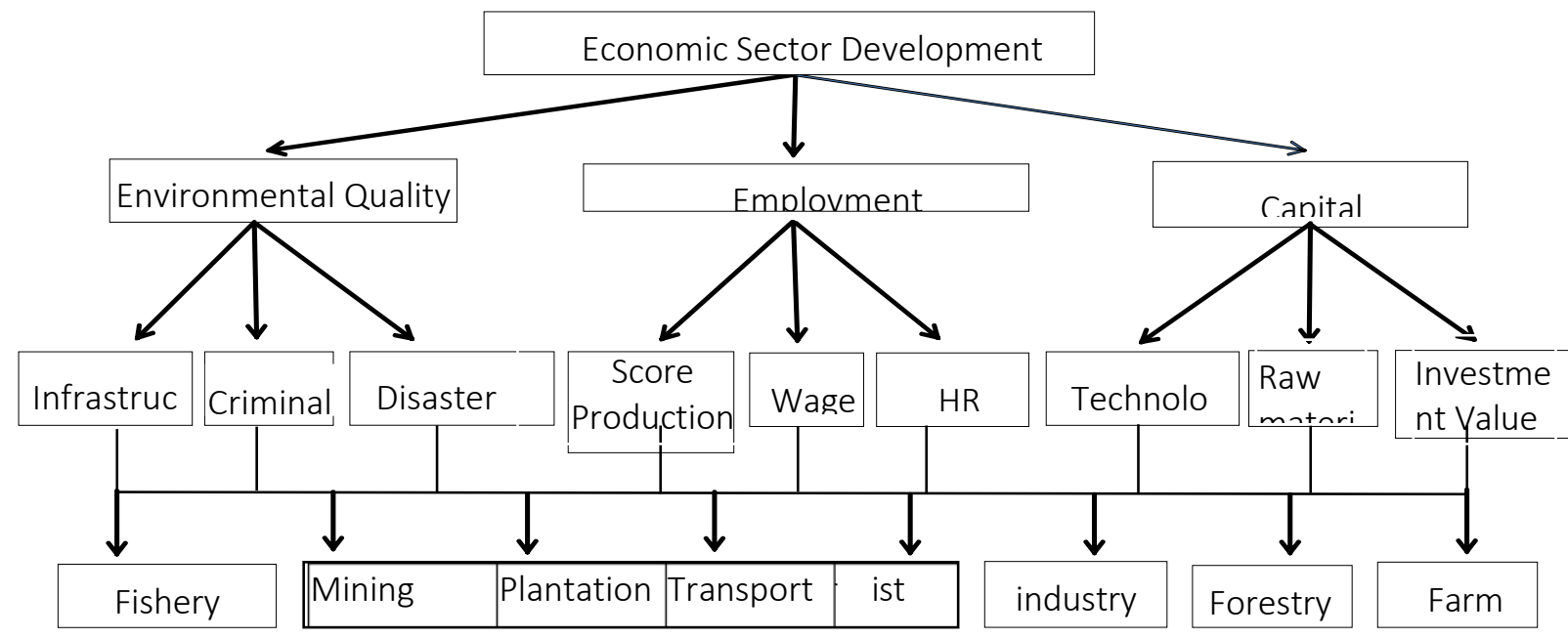

Figure 4 Process Hierarchy Analysis Matrix

Comparative judgment is often also referred to as criteria or alternative assessment. At this stage, a pairwise comparison of all elements in the hierarchy will be made, with the aim of generating a scale of importance for each element. The assessment carried out will produce a number which will later be compared to produce a priority. The number scale used is one to nine which is then compiled to obtain pairwise comparisons. The comparison scale used is:

Table 4. AHP Comparison Scale

\begin{tabular}{cl}
\hline Scale & \multicolumn{1}{c}{ Information } \\
\hline 1 & One goal with another is just as important \\
3 & One goal is a little more important (somewhat strong) than the other \\
5 & One goal is more important (stronger importance) than the other \\
7 & One goal is more important than the other \\
9 & One extreme goal is more important than the other goal \\
$2,4,6,8$ & The middle value between the two assessment scores above \\
\hline
\end{tabular}

\section{RESULTS AND DISCUSSIONS}

The first level is to determine the level of importance between each criterion objective based on the results of the analysis that has been carried out, the level of importance obtained is presented in the following table.

Table 5. Results of Weight Calculation Objectives of Process Hierarchy Analysis (AHP)

\begin{tabular}{clcc}
\hline No & \multicolumn{1}{c}{ Criteria } & Priority Vector & Weight (\%) \\
\hline 1 & Market Availability & 0.316 & 31.6 \\
2 & Employment & 0.441 & 44.1 \\
3 & Capital & 0.243 & 24.3 \\
\hline
\end{tabular}

Consistency Ratio $(\mathrm{CR})=0.0021$

Source: AHP Output, 2021

Table 5 shows the results of the calculation of the objective weighting of the process hierarchy analysis (AHP). based on the calculation results obtained the value of Consistency Ratio $(C R)=0.0021$ which is less than 0.10 . This shows that the pairwise comparison matrix between criteria is consistent. Then, to determine which sub-sectors will be prioritized from the economic sector, the most important criteria objectives to use are market availability with a weighted value of $31.6 \%$, then employment with a weighted value of $44.1 \%$ and the objective of capital criteria with a weighted value of $24.3 \%$.

This is in accordance with Meilani's research entitled analysis of labor absorption in the city of Magelang with the process hierarchy analysis (AHP) method (2014), showing that the use of AHP can 
be applied to see strategies that can be used to solve unemployment problems. In this study, primary data is used as policy formulation in the Process Hierarchy Analysis (AHP) obtained from keypersons, including determining criteria in order to achieve the goal of reducing unemployment, determining in the selection of alternative programs that can be taken to reduce unemployment.

The next step is the Determination of Priority Subsector Determination with Criteria, based on the results of the analysis that has been carried out, the results obtained are shown in the following table:

Table 6. Results of the Calculation of Interest Weights Market Availability Criteria

\begin{tabular}{clcc}
\hline No & \multicolumn{1}{c}{ Criteria } & Priority Vector & Weight (\%) \\
\hline 1 & Infrastructure & 0.321 & 32.1 \\
2 & Criminal & $0.401^{*}$ & 40.1 \\
3 & Disaster & 0.278 & 27.8 \\
\hline
\end{tabular}

Consistency Ratio $(\mathrm{CR})=0.00336$

Source: AHP Output, 2021

Table 6 shows the results of the calculation of the weight of the market availability criteria. The calculation results obtained the Consistency Ratio $(C R)=0.00336$ which is less than 0.10 , this indicates that the pairwise comparison matrix between sub-criteria for sub-sector growth is consistent. Then, the sub-criteria that has the largest priority vector is the security sub-criteria with a priority vector of 0.401 or if it is weighted by $40.1 \%$, then Infrastructure with a priority vector of 0.321 or if it is weighted by $32.1 \%$, and the last is Price with priority vector of 0.278 or if it is weighted by $27.8 \%$.

Labor absorption is the number of jobs that have been filled, which is reflected in the large number of working people. The working population is absorbed and scattered in various sectors of the economy. The absorption of the working population is caused by the demand for labor. In this study, people's perceptions related to the economic sector by considering the criteria for employment with sub-criteria for production value, wages, and human resources.

Table 7. Calculation of Interest Weight Calculation of Labor Absorption Criteria

\begin{tabular}{clcc}
\hline No & \multicolumn{1}{c}{ Criteria } & Priority Vector & Weight (\%) \\
\hline 1 & Production Value & 0.256 & 25.6 \\
2 & Wages & 0.197 & 19.7 \\
3 & HR & $0.547^{*}$ & $54.7^{*}$ \\
\hline
\end{tabular}

Consistency Ratio $(C R)=0.00097$

Source: AHP Output, 2021

Table 7 shows the results of the calculation of the weight of interest in the criteria for labor absorption. The calculation results obtained the Consistency Ratio $(C R)=0.00097$ which is less than 0.10 , this indicates that the pairwise comparison matrix between the sub-criteria for employment is consistent. Then, the sub-criteria that has the largest priority vector is the HR sub-criteria with a priority vector of 0.547 or if it is weighted by $54.7 \%$, then the value of production facilities with a priority vector is 0.256 or if it is weighted by $25.6 \%$, and lastly is wages with priority vector of 0.197 or if weighted by $19.7 \%$.

Table 8. Calculation Result of Interest Weight of Capital Criteria

\begin{tabular}{clcc}
\hline No & \multicolumn{1}{c}{ Criteria } & Priority Vector & Weight (\%) \\
\hline 1 & Technology & 0.311 & 31.1 \\
2 & Raw material & 0.433 & 43.3 \\
3 & Investment Value & $0.256^{*}$ & $25.6^{*}$ \\
\hline
\end{tabular}

Consistency Ratio (CR) $=0.00766$

Source: AHP Output, 2021 
Table 8 shows the results of the calculation of the weight of the capital criteria. The calculation results obtained the Consistency Ratio $(C R)=0.00766$ which is less than 0.10 , this indicates that the pairwise comparison matrix between the sub-criteria for increasing competitiveness is consistent. Then, the sub-criteria that has the largest priority vector is the raw material sub-criteria of 0.433 or if it is weighted by $43.3 \%$, then technology with priority vector is 0.311 or if it is weighted by $31.1 \%$, and Investment Value with priority vector is 0.256 or if weighted by $25.6 \%$.

After determining the weight of the criteria in determining the priority sub-sector with criteria, the next step is to use the weight of the criteria (Infrastructure, security, prices, production facilities, wages, human resources, technology, raw materials, investment value) to determine alternative economic priority sub-sectors in West Coast District. These criteria will be used to select the priority sub-sectors of the economy, namely Fisheries, Mining, Plantations, Transportation, Tourism, Industry, Forestry, Livestock. The results of the estimated data are shown in the following table:

The role of infrastructure in the production process as well as in supporting the distribution of economic commodities is very important. Telecommunications, electricity, and water are very important elements in the production process of economic sectors such as trade, industry, and agriculture.

Table 9. Results of The Calculation of Interests In The Processing Industry Subsector Criteria For Infrastructure

\begin{tabular}{clccc}
\hline No & Alternative Subsector & Priority Vector & Weight (\%) & Rank \\
\hline 1 & Fishery & 0.160 & 16.0 & 2 \\
2 & Mining & 0.050 & 5.0 & 8 \\
3 & Plantation & 0.080 & 8.0 & 3 \\
4 & Transport & 0.070 & 7.0 & 7 \\
5 & Tourist & 0.350 & 35.0 & 1 \\
6 & Industry & 0.080 & 8.0 & 6 \\
7 & Forestry & 0.100 & 12.0 & 5 \\
8 & farm & 0.110 & 10.0 & 4 \\
\hline
\end{tabular}

Consistency Ratio $(\mathrm{CR})=0.00822$

Source: AHP Output, 2021

Table 9 shows the results of the calculation of the weighting of interests in the processing industry sub-sector infrastructure criteria. From the calculation results, the CR value of the comparison between the criteria for raw materials and alternative sub-sectors is less than 0.1 , which is 0.00822 . This shows that the pairwise comparison matrix between alternatives is consistent. Then the highest priority alternative for tourism criteria is obtained with a Priority Vector value of 0.350 or if it is weighted by $35 \%$.

Community Security and Order is a dynamic condition of society as one of the prerequisites for the implementation of the national development process in the context of achieving national goals marked by ensuring security, order and law enforcement, as well as the establishment of peace, which contains the ability to foster and develop the potential and strength of the community in preventing , prevent, and overcome all forms of law violations and other forms of disturbance that can disturb the public.

Table 10. Result of Calculation of Interest Weight of Processing Industry Sub-Sector Criminal Criteria

\begin{tabular}{clccc}
\hline No & Alternative Subsector & Priority Vector & Weight (\%) & Rank \\
\hline 1 & Fishery & 0.160 & 16 & 2 \\
2 & Mining & 0.050 & 5 & 8 \\
3 & Plantation & 0.080 & 8 & 3 \\
4 & Transport & 0.070 & 7 & 7 \\
5 & Tourist & 0.350 & 35 & 1 \\
6 & Industry & 0.080 & 8 & 6 \\
7 & Forestry & 0.110 & 11 & 5 \\
\hline
\end{tabular}




\begin{tabular}{ccccc}
\hline No & Alternative Subsector & Priority Vector & Weight (\%) & Rank \\
\hline 8 & farm & 0.100 & 10 & 4 \\
\hline
\end{tabular}

Consistency Ratio $(\mathrm{CR})=0.061$

Source: AHP Output, 2021

Table 10 shows the results of the calculation of the weighting of the interests of the processing industry sub-sector of the security criteria. From the calculation results, the CR value of the comparison between the safety criteria is less than 0.1 , which is 0.061 . This shows that the pairwise comparison matrix between alternatives is consistent. Then the highest priority alternative for security criteria is obtained, namely the tourism sub-sector with a Priority Vector value of 0.350 or if it is weighted by $35.0 \%$.

Table 11. Result of Calculation of Interest Weight of Processing Industry Subsector Disaster Criteria

\begin{tabular}{clccc}
\hline No & Alternative Subsector & Priority Vector & Weight (\%) & Rank \\
\hline 1 & Fishery & 0.210 & 21 & 2 \\
2 & Mining & 0.010 & 1 & 8 \\
3 & Plantation & 0.150 & 15 & 4 \\
4 & Transport & 0.050 & 5 & 7 \\
5 & Tourist & 0.270 & 27 & 1 \\
6 & Industry & 0.060 & 6 & 6 \\
7 & Forestry & 0.070 & 7 & 5 \\
8 & farm & 0.180 & 18 & 3 \\
\hline
\end{tabular}

Consistency Ratio (CR) $=0.06$

Source: AHP Output, 2021

Table 11 shows the results of the calculation of the weighting of interests in the processing industry sub-sector price criteria. From the results of the AHP calculation, the CR value of the comparison between the quality criteria of the workforce against the alternative sub-sectors for all expert groups, namely the government, private sector, and community institutions is less than 0.1, which is 0.06 . This shows that the pairwise comparison matrix between alternatives is consistent. Then the highest priority alternative for the price criteria is obtained, namely the tourism sub-sector with a Priority Vector value of 0.270 or if it is weighted by $27 \%$.

Table 12. Result of Calculation of Interest Weight of Processing Industry Sub-Sector Criteria for

\begin{tabular}{clccc}
\multicolumn{5}{c}{ Production Facilities } \\
\hline No & Alternative Subsector & Priority Vector & Weight (\%) & Rank \\
\hline 1 & Fishery & 0.230 & 23 & 2 \\
2 & Mining & 0.030 & 3 & 8 \\
3 & Plantation & 0.180 & 18 & 3 \\
4 & Transport & 0.050 & 5 & 6 \\
5 & Tourist & 0.300 & 30 & 1 \\
6 & Industry & 0.040 & 4 & 7 \\
7 & Forestry & 0.070 & 7 & 5 \\
8 & farm & 0.100 & 10 & 4 \\
\hline
\end{tabular}

Consistency Ratio $(\mathrm{CR})=0.031$

Source: AHP Output, 2021

Table 12 shows the results of the calculation of the weighting of interests in the processing industry sub-sector criteria for production facilities. From the results of the AHP calculation, the CR value of the comparison between the criteria for the production value of the alternative sub-sector is less than 0.1 , which is 0.031 . This shows that the pairwise comparison matrix between alternatives is 
consistent. Then the highest priority alternative for the production criteria is obtained, namely the Tourism sub-sector with a Priority Vector value of 0.300 or if it is weighted by $30 \%$.

Table 13. Result of Calculation of Interest Weight of Processing Industry Subsector Wage Criteria

\begin{tabular}{llccc}
\hline No & Alternative Subsector & Priority Vector & Weight (\%) & Rank \\
\hline 1 & Fishery & 0.190 & 19 & 2 \\
2 & Mining & 0.020 & 2 & 8 \\
3 & Plantation & 0.150 & 15 & 3 \\
4 & Transport & 0.050 & 5 & 6 \\
5 & Tourist & 0.350 & 35 & 1 \\
6 & Industry & 0.030 & 3 & 7 \\
7 & Forestry & 0.090 & 9 & 5 \\
8 & farm & 0.120 & 12 & 4 \\
\hline
\end{tabular}

Consistency Ratio $(C R)=0.0281$

Source: AHP Output, 2021

Table 13 shows the results of the calculation of the weight of interest in the processing industry sub-sector of wage criteria. From the results of the AHP calculation, the CR value of the comparison between wage criteria against alternative sub-sectors is less than 0.1 , which is 0.0281 . This shows that the pairwise comparison matrix between alternatives is consistent. Then the highest priority alternative for wage criteria is obtained, namely the Tourism sub-sector with a Priority Vector value of 0.350 or if it is weighted by $35 \%$.

This is like the results of Sihotang's linear research in a study entitled Analysis of the Planning Strategy for the Development of the Processing Industry Subsector in South Tangerang City. is on the growth of its sub-sector, and the sub-criteria of science and technology is something that must be prioritized. For alternative industrial sub-sectors, the focus is on the food and beverage industry in South Tangerang City itself.

Table 14. Result of Calculation of Interest Weight of Processing Industry Sub-Sector HR Criteria

\begin{tabular}{llccc}
\hline No & Alternative Subsector & Priority Vector & Weight (\%) & Rank \\
\hline 1 & Fishery & 0.150 & 15 & 3 \\
2 & Mining & 0.020 & 2 & 8 \\
3 & Plantation & 0.200 & 20 & 2 \\
4 & Transport & 0.080 & 8 & 6 \\
5 & Tourist & 0.280 & 28 & 1 \\
6 & Industry & 0.060 & 6 & 7 \\
7 & Forestry & 0.100 & 10 & 5 \\
8 & farm & 0.110 & 11 & 4 \\
\hline
\end{tabular}

Consistency Ratio $(\mathrm{CR})=0.0892$

Source: AHP Output, 2021

Table 14 shows the results of the calculation of the weighting of interests in the processing industry sub-sector of HR criteria. From the results of the AHP calculation, the CR value of the comparison between the criteria for the investment value of the alternative sub-sector is less than 0.1, which is 0.0829 . This shows that the pairwise comparison matrix between alternatives is consistent. Then the highest priority alternative for HR criteria is obtained, namely the Tourism sub-sector with a Priority Vector value of 0.280 or if it is weighted by $28 \%$. 
Table 15. Result of Calculation of Interest Weight of Processing Industry Subsector Technology Criteria

\begin{tabular}{llccc}
\hline No & Alternative Subsector & Priority Vector & Weight (\%) & Rank \\
\hline 1 & Fishery & 0.200 & 20 & 2 \\
2 & Mining & 0.060 & 6 & 7 \\
3 & Plantation & 0.150 & 15 & 3 \\
4 & Transport & 0.030 & 3 & 8 \\
5 & Tourist & 0.250 & 25 & 1 \\
6 & Industry & 0.090 & 9 & 6 \\
7 & Forestry & 0.120 & 12 & 4 \\
8 & farm & 0.100 & 10 & 5 \\
\hline
\end{tabular}

Consistency Ratio (CR) $=0.0987$

Source: AHP Output, 2021

Table 15 shows the results of the calculation of the weighting of interests in the processing industry sub-sector technology criteria. With the CR value, the comparison between infrastructure criteria and sub-sector alternatives for all expert groups, namely the government, private sector, and community institutions, is less than 0.1 , which is 0.0987 . This shows that the pairwise comparison matrix between alternatives is consistent. Then the highest priority alternative for the Technology criteria is obtained, namely the Tourism sub-sector with a Priority Vector value of 0.250 or if it is weighted by $25 \%$.

Table 16. Result of Calculation of Interest Weight of Processing Industry Sub-Sector Criteria for Raw Materials

\begin{tabular}{clccc}
\hline No & Alternative Subsector & Priority Vector & Weight (\%) & Rank \\
\hline 1 & Fishery & 0.220 & 22 & 2 \\
2 & Mining & 0.020 & 2 & 8 \\
3 & Plantation & 0.090 & 9 & 5 \\
4 & Transport & 0.080 & 8 & 6 \\
5 & Tourist & 0.240 & 24 & 1 \\
6 & Industry & 0.070 & 7 & 7 \\
7 & Forestry & 0.100 & 10 & 4 \\
8 & farm & 0.180 & 18 & 3 \\
\hline
\end{tabular}

Consistency Ratio (CR) $=0.0277$

Source: AHP Output, 2021

Table 16 shows the results of the calculation of the weighting of interests in the processing industry subsector criteria for raw materials. From the results of the AHP calculation, the CR value of the comparison between the bureaucratic criteria and the alternative sub-sector is less than 0.1 , which is 0.0277 . This shows that the pairwise comparison matrix between alternatives is consistent. Then the highest priority alternative is obtained for the raw material criteria, namely the tourism sub-sector with a Priority Vector value of 0.240 or if it is weighted by $24 \%$.

Table 17. Result of Calculation of Interest Weight of Processing Industry Subsector Investment Value Criteria

\begin{tabular}{clccc}
\hline No & Alternative Subsector & Priority Vector & Weight (\%) & Rank \\
\hline $\mathbf{1}$ & Fishery & 0.250 & 25 & 2 \\
$\mathbf{2}$ & Mining & 0.020 & 2 & 8 \\
$\mathbf{3}$ & Plantation & 0.100 & 10 & 4 \\
$\mathbf{4}$ & Transport & 0.030 & 3 & 7 \\
$\mathbf{5}$ & Tourist & 0.330 & 33 & 1 \\
\hline
\end{tabular}




\begin{tabular}{clccc}
\hline No & Alternative Subsector & Priority Vector & Weight (\%) & Rank \\
\hline $\mathbf{6}$ & Industry & 0.080 & 8 & 5 \\
$\mathbf{7}$ & Forestry & 0.060 & 6 & 6 \\
$\mathbf{8}$ & farm & 0.130 & 13 & 3 \\
\hline
\end{tabular}

Consistency Ratio $(\mathrm{CR})=0.0871$

Source: AHP Output, 2021

Table 17 shows the results of the calculation of the weighting of interests in the processing industry subsector of investment value criteria. From the results of the AHP calculation, the CR value of the comparison between HR criteria and alternative sub-sectors is less than 0.1 , which is 0.0871 . This shows that the pairwise comparison matrix between alternatives is consistent. Then the highest priority alternative is obtained for the Investment Value criteria, namely the Tourism sub-sector with a Priority Vector value of 0.330 or if it is weighted by $33 \%$.

Based on all the criteria choices made in determining the priority or superior sub-sectors, the total criteria selection factors are obtained, namely:

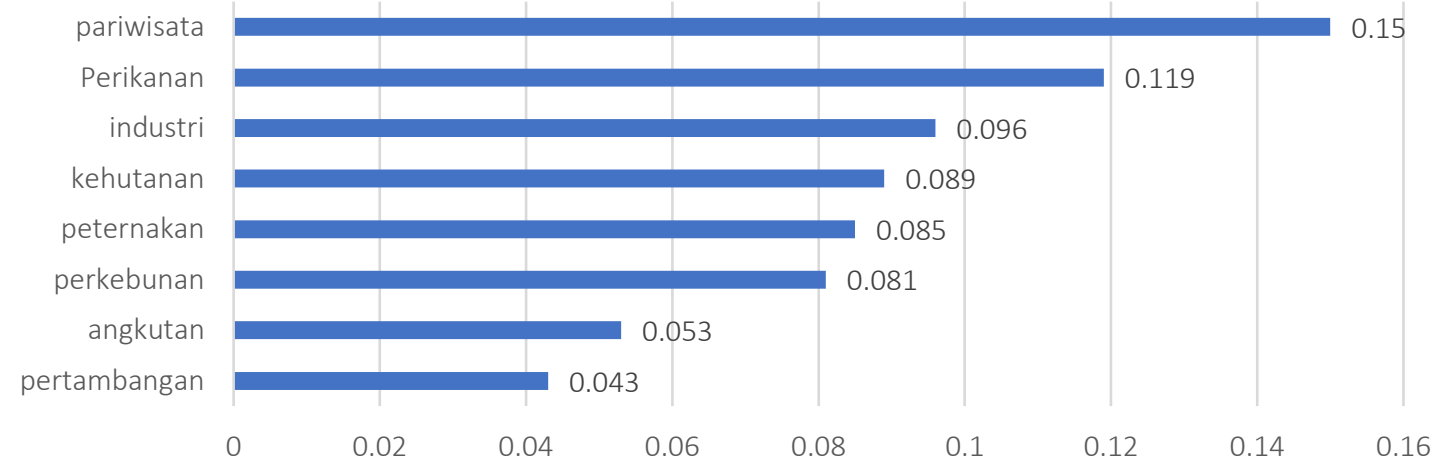

Figure 5. Total Matrix of Process Hierarchy Analysis.

Based on regional development goals, the tourism sector has a weighted value of 0.150 , this shows that the tourism sector in West Coast District is the sector most desired by the community to be developed. And the sector with the lowest value weight is the mining sector.

Research with similar results was carried out by Pradigda, in 2016 conducting research on Strategic Development Planning for Regional Superior Products, Studies at the Industry and Trade Office of Blitar District. This study aims to determine the superior product that is prioritized or called the priority superior product in Blitar District, which is the location for its development. The analytical method used in this research is shift-share analysis and Analytical Hierarchy Process (AHP). The results of this research are, which includes the leading commodity of Blitar District is coconut shell craft, and the priority development strategy of coconut shell craft based on the SWOT matrix, namely the strategy Strength-Opportunity (SO).

\section{CONCLUSIONS}

Theory Zamor (1985) which states that community participation in development will help in the development process can be seen through this research, in this study the role of the community is seen by asking for their opinion on the priority economic sector to be built and developed. Based on public perception, there are several economic sectors that are expected to be prioritized for the development of the economic sector.

Based on the calculation results, it is obtained that the priority sub-sectors that want to be developed from the economic sector in the west coast district, in regional development, the community wants the economic sector to be developed is a sector with labor absorption, with a 
weighting value of market availability of $44.1 \%$, this shows public perception the development of the economic sector is to absorb labor, the community wants the development of the economic sector to absorb labor. Based on the data in figure 1 shows the open unemployment rate which has increased from 2019 to 2021. Then followed by Environmental Quality with a weighted value of $31.6 \%$, and capital criteria with a weighted value of $24.3 \%$. In the context of economic development in the West Coast District, the criteria that are used as the focus are employment, by concentrating on the growth of its sub-sector. Furthermore, from the sub-sector the main criteria are HR with a weighted value ofof $54.7 \%$, this is in accordance with the existing theory in economics, that good human resources will increase the absorption of labor which results in a decrease in the unemployment rate. The economic sub-sector that is the priority of development based on public perception is the tourism sector with a weighting value of 0.15 , followed by the fisheries sector with a weighting of 0.119 and the industrial sector 0.096 .

\section{ACKNOWLEDGEMENT}

Thanks to the adviser who always give encouragement and support to the Prof. Dr. Toto Gunarto, S.E., M. Si. and Dr. Neli Aida, S.E., M. on the evaluation of this article, thanks also to the Faculty of Economics and Business, Master of Economics, University of Lampung, Indonesia.

\section{REFERENCES}

Ahmad, Zaini. 2018. "Determination of the Economic Sector in East Kalimantan, Indonesia." Journal of Chinese Economic and Foreign Trade Studies 11(3):182-201. doi:10.1108/jcefts-01-2018-0001.

Ahmadi Esfahani, Navid, and Mohsen Shahandashti. 2020. "Post-Hazard Labor Wage Fluctuations: A Comparative Empirical Analysis among Different Sub-Sectors of the US Construction Sector." Journal of Financial Management of Property and Construction 25(3):313-30. doi:10.1108/JFMPC-07-2019-0063.

Arsyad, Lincoln. 1999. Introduction to Regional Economic Planning and development. BPFE-Yogyakarta. Yogyakarta.

Hambali, A., SM Sapuan, N. Ismail, and Y. Nukman. 2009. "Application of Analytical Hierarchy Process (AHP) and Sensitivity Analysis for Selecting the Best Design Concepts during Conceptual Design Stage." Multidiscipline Modeling in Materials and Structures 5(3):289-94. doi:10.1163/157361109789017032.

Kim, Eunja, Changfeng Chen, Tao Pang, and Young Hee Lee. 1999. “Ordering of Dimer Vacancies on the Si(100) Surface." Physical Review B - Condensed Matter and Materials Physics 60(12):8680-85. doi:10.103/PhysRevB.60.8680.

Liu, Linda Boardman, Paul Berger, Amy Zeng, and Arthur Gerstenfeld. 2008. "Applying the Analytic Hierarchy Process to the Offshore Outsourcing Location Decision." Supply Chain Management 13(6):435-49. doi: 10.1108/13598540810905697.

Ong, Seow Eng, and Teck lan Chew. 1996. "Singapore Residential Market: An Expert Judgmental Forecast Incorporating the Analytical Hierarchy Process." Journal of Property Valuation and Investment 14(1):50-66.

Resbeut, Mathieu, and Philippe Gugler. 2016. "Impact of Clusters on Regional Economic Performance." Competitiveness Review 26(2):188-209. doi:10.1108/cr-09-2015-0078.

Sevkli, Mehmet, SC Lenn. Koh, Selim Zaim, Mehmet Demirbag, and Ekrem Tatoglu. 2008. "Hybrid Analytical Hierarchy Process Model for Supplier Selection." Industrial Management and Data Systems 108(1):122-42. doi: 10.1108/02635570810844124.

Siregar, 2006, "Improving Economic Structure and Growth: Encouraging Investment and Creating Jobs", Journal of Political Economy and Finance, INDEF, Jakarta.

Snowden, Kate. 2007. "Competitiveness Review: An International Business Journal Changes Publisher." Competitiveness Review 17(1/2). doi:10.1108/cr.2007.34717aaa.001.

Spee, Roel, and Wim Douw. 2004. "Cost-Reduction Location Strategies." Journal of Corporate Real Estate 6(1):30-38. doi:10.1108/14630010410812225. 
Sugiyono. (2012). Understanding Qualitative Research". Bandung : ALFABETA.

Suyono, Rudi S and Mukti, Elsa T. (2009). The Use of Analytical Hierarchy Process Method (PHA) in Site Selection for Relocation of Rahadi Oesman Airport, Ketapang, West Kalimantan. XII FSTPT Symposium. November 2009. pp. 527-543. Surabaya

Zamor GC, 1985, Public Participation in Development Planning and Management, cases from Africa and Asia, West View Press, London, p. 39 etc. 